\title{
On the Rights of Temporary Migrants ${ }^{1}$
}

\author{
Christian Barry (ANU) \& Luara Ferracioli (UvA)
}

(Forthcoming at The Journal of Legal Studies)

\begin{abstract}
Temporary workers stand to gain from temporary migration programs, which can also benefit sender and recipient states. Some critics of temporary migration programs, however, argue that failing to extend citizenship rights or a secure pathway to permanent residency to such migrants places them in an unacceptable position of domination with respect to other members of society. We shall argue that access to permanent residency and citizenship rights should not be regarded as a condition for the moral permissibility of such programs. Instead we will focus on the essential protections that must be extended to all migrant workers, irrespective of the length of their migration project.
\end{abstract}

Temporary workers stand to gain from temporary migration programs, which can also benefit the countries that receive them and their countries of origin. ${ }^{2}$ Some critics of temporary migration programs, however, argue that failing to extend full political rights or providing a secure pathway to permanent residency or citizenship to such migrants places them in an unacceptable position of domination with respect to other members of society. These critics raise very important concerns about temporary migration programs, many of which have been deeply problematic. Against them, however, we shall argue that access to permanent residency and political rights should not be regarded as a

\footnotetext{
${ }^{1}$ We thank Ryan Cox, Alasia Nuti, Valeria Ottonelli, Lea Ypi, and anonymous reviewers of the Journal of Legal Studies for written comments on an earlier version of this essay, and to the participants of the Conference on the Optimal Design of Guest Worker Programs, at the University of Chicago in 2016 for discussion.

2 The gains such programs might afford are debatable. Optimists like Dani Rodrik (2005, p. 208) have claimed that expanding them could "produce the largest possible gains for the world economy and for poor countries in particular," in comparison with other policies, such as trade liberalization." A World Bank Report (2006, p. 31) claims "movement of 14.2 million workers from developing countries to highincome countries by the year 2025 would yield income gains of $\$ 356$ billion-an 0.6 percent increase in global income." It claims "The scenario is particularly beneficial to developing countries relative to highincome countries. The aggregate percentage gain to developing countries (including the new migrants) is 1.8 percent."
} 
condition for the moral permissibility of such programs. We also identify the essential protections that must be extended to all migrant workers.

Temporary migration programs take diverse forms. Some involve high-skilled workers, while others involve low-skilled workers. Some are of quite short duration, while others are of much longer duration. ${ }^{3}$ Some programs may restrict the rights to work extended to migrants to specific employers or sectors, while others may extend rights to work more generally. Further, the rights other than rights to work that are extended to these migrants may vary (Ruhs 2006, p. 13). What distinguishes temporary migration programs from other mechanisms through which cross-border flow of workers can take place is that they extend temporary working rights to non-citizens without guarantee that they will be permitted to remain and work in the state once their visa expires. ${ }^{4}$

Defined in this way, the question of whether states have a right to control their borders is clearly connected to the issue of whether and when temporary migration programs can ever be permissible. After all, such programs make the extension of permanent residency or citizenship at the discretion of the receiving state, and a fortiori also a right to exclude temporary migrants once their visas expire. Here we'll assume that states possess a right to exclude prospective immigrants. ${ }^{5}$ We shall also assume, however, that morality requires that states regard all persons as having equal basic moral status, and that this norm restricts the way states can exercise their right to exclude. These assumptions are not uncontroversial. Advocates of open borders take issue with the first assumption, for example. We take these assumptions as our starting point since they are quite widely shared, and because those whose arguments we shall engage with in this essay affirm them.

\footnotetext{
${ }^{3}$ See Djajić 2013, for an overview.

${ }^{4}$ We draw here on the account spelled out in Ruhs 2006.

${ }^{5}$ For various approaches to grounding such a right, see Wellman 2008; Blake 2013; Pevnick 2011; Miller 2016.
} 


\section{INTERESTS AT STAKE IN TEMPORARY MIGRATION}

Let's begin by considering the key interests at stake in temporary migration programs. ${ }^{6}$

First, there are the interests of people within the states receiving the temporary workers. Second, there are the interests of the temporary workers themselves. Third, there are the interests of the citizens of the countries from which the temporary workers are drawn. Programs may serve each of these interests in some measure, or they may serve some at the expense of others, depending on the contexts in which they are implemented and the way they are designed. Promoting any one type of interest—say of prospective participants in temporary migration regimes_-may also involve trade-offs. Martin Ruhs and Philip Martin (2008), for example, have shown that when it comes to regulating lowskilled labor immigration, there is a negative relationship between the number of migrants received and the extensiveness of the rights that they are given. ${ }^{7}$ This indicates that there can be trade-offs between the number of temporary migrants whose interests are promoted through a program and the extent to which they are promoted.

Consider first the interests of people in the receiving countries. The reasons why states implement temporary migration are varied. They may be motivated by protecting the material interests of their people by responding to low or negative population growth, or to avoid labor gaps in specific domestic industries (be they low or high skilled industries) (IOM (International Organization for Migration) 2010, p. 13). ${ }^{8}$ They may also have other-regarding interests, for example to promote post-colonial ties with countries of origin, to promote the well-being of the workers who participate in such programs, or

\footnotetext{
${ }^{6}$ The order in which we present them does not a view about their relative importance.

7 As Joseph Carens (2008, p. 439) observes, "the net effect of insisting on granting temporary workers most of the same rights as citizens and residents is that many potential temporary workers will never be able to gain legal admission at all.”

${ }^{8}$ We recognize that programs involving high and low-skilled workers raise distinct challenges, on which more below.
} 
to promote development more generally (Ruhs 2006, p. 13). On the other hand programs may also undermine the interests of some people within the receiving country. For instance, a government might seek to benefit firms or industries at the expense of domestic workers by replacing them (or threatening to replace them) with temporary workers. Or they might employ such programs to undercut the wages or bargaining power of domestic workers. And even if such programs generally serve the material interests of citizens, they may undermine their other-regarding interests in not subjecting people in their midst to certain forms of treatment. Some programs, for instance, may not protect the basic rights of migrants, leaving them subject to abuse and without meaningful legal recourse. Consequently, citizens may have duties not to enable the rights violations of those residing in their territory. These considerations can also ground moral complaints against temporary migration programs.

Consider next the interests of the temporary workers. Since such temporary migration programs are typically voluntary, the migrants themselves seem to perceive them to be in their interests. Temporary workers may increase their income, savings, and set of skills (IOM 2010, p. 53). Savings render these workers better insured against the risk of unemployment in their home countries, and the acquisition of new skills can increase their employment prospects once they return home (Ruhs 2006, p. 26). Temporary workers may also have moral interests in bringing resources, skills and knowledge back to their country of origin to benefit others.

To be sure, there is no guarantee that their material interests will be promoted by such programs. They may receive far less income than they imagined or were contractually entitled to, or be subject to various forms of abuse, or even be unable to exercise their rights to exit the host country. Consequently, temporary migrants may be made worse 
off than they would have been had they adopted other options that were available to them. ${ }^{9}$

Finally, temporary migration may also promote development in the country of origin. Temporary migrants, especially the low skilled among them, often remit to their families while working abroad. ${ }^{10}$ Remittances can have positive impacts in remittance-receiving countries. They can increase the basic income of recipient households, enable the recipient households to make investments in education, health and housing, and to contribute to the creation of small enterprises. ${ }^{11}$

Remittances may also have significant positive indirect effects. Devesh Kapur and John McHale (2012) have suggested that the fact that remittances go directly to recipient households and do not need to pass through the state also carries significant benefits. By providing an independent source of resources from the state, remittances may loosen patronage systems and increase the feasibility of political change and institutional reform (see for instance Pfutze 2009). This can arguably be attributed to that population's decreased dependency on the state for aid and social programs.

This is not to suggest that remittances have no negative effects on the receiving country. Remittances can help fuel conflict and civil war. ${ }^{12}$ Furthermore, over-reliance on them may create macroeconomic problems in the receiving country. ${ }^{13}$ The possibility of sending back remittances may also encourage "brain drain." ${ }^{14}$ In a world without remittances, more of a poor country's best workers would stay home, though what

\footnotetext{
${ }^{9}$ These harms can also give rise to moral complaints against such programs, especially in cases where the harms were foreseeable by the relevant authorities yet not adequately communicated to prospective guest workers.

${ }^{10}$ Empirical studies suggest that temporary and circular migration lead to higher levels of remittances. See Dustmann and Mestres 2010; De Haas 2005.

${ }^{11}$ A World Bank study found that a 10 percent increase in international migration (the percentage of a country's population that lives abroad) is correlated with a 1.9 percent decrease in poverty. See Adams Jr. and John Page 2005, pp. 1648-1651.

12 See Collier and Hoeffler, 2002, p. 6 and p. 8 (correlating rebel groups' funding, potentially obtained through remittances from diaspora in developed nations, with incidences of civil war around the world).

${ }^{13}$ See World Bank 2006, p. 125 (explaining the distortive effect that local spending of remittance income has on the inflation rates and monetary policies of recipient countries).

${ }^{14}$ For a discussion of the ethics of the brain drain, see Brock and Blake 2014; Ferracioli 2015.
} 
overall effect this will have will depend a great deal on the opportunities available to them. It has proven difficult to show that remittances have had a substantial effect on economic growth, and some have argued that they engender moral hazard (see Clemens and McKenzie 2014; Chami, Fullenhkamp, and Jahjah 2003).

\section{TEMPORARY MIGRATION AND CITIZENSHIP RIGHTS}

Many who have criticized temporary migration programs do not challenge the empirical claim that these programs can give rise to substantial economic benefits. Instead, their concern is that, independent of the economic benefits that temporary workers may acquire, the exclusion of temporary migrants from the political arena and their lack of access to permanent residency places them in an unacceptable position with respect to other members of society. Michael Walzer (2008, pp. 59-60) argues, famously, that the exercise of power on the part of citizens over guest workers who resemble citizens in the social, economic, and legal domains leads to a modern kind of social tyranny. Note that Walzer is not challenging the right of states to exclude, but placing conditions on their right to include. He writes "the processes of self-determination through which a democratic state shapes its internal life, must be open, and equally open, to all those men and women who live within its territory, work in the local economy, and are subject to local law." On his view, those "subject to the state's authority" must be "given a say ... in what that authority does" (Walzer 2008, pp. 59-60). Walzer even claims that a society where guest workers are denied political rights is morally on a par to ancient Athens, where foreign-born permanent residents (the metics) shared all the burdens of citizenship without ever enjoying any of the social benefits (Walzer 2008, pp. 59-60). Others have developed related critiques. Theodora Kostakopoulou (2009, p. 279), for instance, argues that a genuine democratic society must not create a subject class of politically 
disempowered individuals. Patti Tamara Lenard and Christine Straehle (2011) have argued that citizenship and permanent residency are jointly necessary for the justifiability of temporary migration programs because these rights make society less willing to exploit temporary workers, while simultaneously making temporary workers less likely to tolerate abuse. And Alex Sager (2014) has argued on Republican grounds that denying political rights to guest workers amounts to an unacceptable exercise of domination over them.

It is the combination of temporary economic integration and political exclusion that has most troubled these critics of temporary migration programs. They maintain that states cannot both invite guest workers to temporarily participate in their labor market and deny them the full range of citizenship rights.

Are these criticisms plausible? They stem from the concern that all people within a country have equal moral status and should therefore be treated as equals. More specifically, failing to treat people as equals with respect to political rights is regarded as putting them in a position in which they are dominated. The idea of equal moral status is compelling, but it is not clear how it should be understood, or what requirements it places on states when it comes to the treatment of different groups of people within its territory. ${ }^{15}$ First, it is important to recognize that equal moral status does not always imply equal treatment. Consider a (very) domestic analogy: we can recognize that a child who lives across the street has equal moral status as our own child, without it implying that we must take her on a holiday with us or pay for her music classes. In this case, we have relevantly different relationships to the two children, and this difference may not only permit but requires that we treat them differently. ${ }^{16}$ Sometimes, however, unequal treatment is impossible to square with equal status. It seems clearly objectionable that

\footnotetext{
${ }^{15}$ As many have pointed out, is also not obvious how the relevant idea of equality can be grounded, but we shall not take up this issue here. For discussion, see Williams 1962; Waldron 2002; Arneson 1999.

16 The degree to which differences in treatment could be warranted would no doubt depend on the relationships to the two children. If the child across the road came to live on our home for a time, this will require that we provide for them in ways that we would not otherwise be required to do.
} 
citizens of a state should be given unequal shares of rights over a lifetime, for example denying some ethnic minority the right to vote or hold office. This would be analogous to denying some children in the neighbourhood access to the local playground. That is, there is no room for second-class citizenship in a society that affirms the equal moral status of persons.

There are some rights which a state is surely obliged to extend to all those within its territory. It must offer basic police protection, due process and trial by jury, for instance. These are rights people need, whatever their life plans and geographic location. What rationale could there be for making the content of a person's right to be free from certain forms of search and seizure, or to enjoy protections under the criminal justice system, contingent on their citizenship status? These are not rights related to jointly determining the future of a community, but which determine how the state and its agents may treat those under their authority.

On the other hand, it seems odd to complain that people who visit some territory for a short time are treated in a way that denies their status as moral equals because they are not immediately provided the full range of rights that are extended to citizens. Are tourists on holiday, an au pair on a 6-month stint, or a visiting academic spending an academic year in a foreign country regarded as having morally inferior status because they are denied the right to vote in a national election that takes place while they are present? Failing to distinguish between short-term visitors and citizens seems to fail to account for the very different relationships in which these people stand to the state. ${ }^{17}$ Interestingly, Walzer himself seems to grant that such people are not entitled to political rights, stating that his argument doesn't apply to privileged guests “technical advisors, visiting professors, and so on" (Walzer 2008, p. 60) But he doesn't explain why these people, who also live in a state, participate in its economy and are subject to its laws lack

\footnotetext{
${ }^{17}$ See Ypi (2016) for a helpful discussion of these issues.
} 
claims to political rights, while guest workers possess them. ${ }^{18}$ Presumably he believes that voting rights play an important instrumental role in securing a range of basic rights for guest workers, whereas in the case of more "privileged" temporary workers, such basic rights are already secured. ${ }^{19}$

Intuitively, short-term temporary visitors, whether economically privileged or not, are not regarded as second-class citizens, but as temporary visitors and workers. Here unequal treatment does not derive from or express a denial of equal moral status. Rather, unequal treatment stems from what seem to be relevant differences between the groups that are treated unequally: members of political associations may possess rights (membership rights) that non-members lack. Temporary visitors have membership rights, but they do not happen to have membership rights in the community that they visit. The package of rights and privileges that a state must extend to different individuals depends on the nature of the relationship between these people and the state. If people are members of the same political community, then they may have rights that other nonmembers lack. Thus, inequalities in rights among members can be objectionable in ways the inequalities between members and non-members may not be. This does not establish that it is always permissible to deny temporary migrants such rights. Rather, it suggests there is not a simple route from recognition of equal moral status for those living and participating in the economic life of a state, to the requirement that the state extends a full range of political rights to them.

There is an important separate question, which concerns when people have a right to become members in a political community. We certainly shouldn't assume that all those who have a moral right to be a full-fledged member of a political community

\footnotetext{
18 These are the conditions Walzer (2008, p. 59) treats as triggers of a right to participate in the processes of self-determination of a community.

${ }^{19}$ We do think there are important differences between some classes of temporary workers and short term temporary visitors. Our point here is that possessing equal moral status and merely being in a state and subject to its laws are not sufficient to generate a claim to political rights within that state.
} 
have their rights legally recognized. Children of denizens who are born and raised in a state that employs the principle of jus sanguinis for citizenship allocation are an obvious example of denizens who are morally entitled to citizenship. If someone has a right to become a member of a political community and they are denied such membership, then this clearly amounts to wrongful treatment. ${ }^{20}$ And it will be wrong, correspondingly, that they are not extended the same rights as those who are legally recognized as members. The same is true of adults who have taken part in a society's economic and social life for so long that they have plausibly acquired a claim to remain and to be regarded as members in full of that community irrespective of their place of origin (Carens 2010). Consequently, temporary migration programs of very long duration may indeed enable migrants to be treated as second-class citizens, rather than visitors of equal moral status who lack membership rights, and should be rejected on this basis. ${ }^{21}$

It is therefore not surprising that in his discussion of temporary migration, Walzer focuses on the Gastarbeiter program adopted by West Germany in the 1950's through to the 70's. Among many of the problems with this program was the fact that many workers stayed for very long periods (through a process of visa renewal), having children and so on, without there being any clear pathway to citizenship. Nor could the spouses of workers or their children acquire work permits. Indeed, other features of the German law aggravated the flaws in the program. Citizenship was generally open only to Ethnic Germans (until 2000), so children of Turkish descent that were born in Germany and lived their entire lives there lacked a legal claim to citizenship. ${ }^{22}$ This program seems a clear instance in which the connection of people to a political community developed in ways that gave them a claim to full membership. Denying people who had lived for a

\footnotetext{
${ }^{20}$ Returning to our domestic analogy - if the child from across the street comes to live with us for a very long time, then at some point they may acquire a right to be a member of the family in full standing.

${ }^{21}$ In what follows we will assume that the programs in question do not allow for very long stays, say exceeding five years.

22 See Chin 2007. The only other class of people who were entitled to citizenship were those with 15 years of residency that were, in addition, considered to be sufficiently 'Germanized'.
} 
long period the rights accorded to others did indeed amount to a form of second-class citizenship, and violated the rights of those relegated to this status. But we shouldn't generalize the contingent features of this program to all temporary migration programs. Programs can be of fixed and much briefer duration, for instance, and rights to work and education can be extended to spouses and children of guest workers. ${ }^{23}$

A few points bear emphasizing. First, we should reject inequality of treatment between two persons or groups within a territory when there are not relevant differences between these groups in their relationship to a state's territory and institutions. Second, there may be some inequalities in treatment that are ruled out by recognizing the equal moral status of all subject to the laws of a state.

Given that it is too quick to assume that equal moral status implies equal treatment, the relevant question for our purpose is whether the rights normally associated with citizenship are also owed to temporary workers. This will depend on the nature of the relationship between temporary workers and the host societies. That is, we need to understand better the nature of this relationship and the rights that must be extended to temporary workers on this basis.

\section{POLITICAL RIGHTS}

Consider first the right to political participation. In recent years, there has been a heated debate on what grounds the right to political participation on the part of competent adults. Some have challenged the conventional view that political participation overlaps neatly with the possession of citizenship, and have advocated that groups who are either affected by political decisions (the all-affected principle), or subjected to these decisions

\footnotetext{
${ }^{23}$ We don't think there is any obvious point at which people come to have membership claims in a society, but some cases seem intuitively to fall on one side of the line and others on the other. A person who works in a country while completing a two-year graduate qualification does not have such a claim, while someone who has lived and worked in that country for 10 years and has started a family does (Carens 2010).
} 
(the all-subjected principle) should have a right to influence them, even if they are not citizens of that state. ${ }^{24}$ There certainly seems to be something to these principles. But they have proven difficult to specify in a plausible way. Consequently, it is not altogether clear how they would apply to temporary workers_-much will depend on how, more precisely, these principles are understood.

This is not to say that citizenship alone should determine access to full rights to political participation. As noted, a denizen resident who has lived and worked in a territory her entire life has a claim to being a full member, whether this claim is honored, and thereby owed rights to political participation. But it is not at all clear that temporary workers have ties to the community that are equivalent to those of permanent residents who are not citizens. Longer-term residents, including some of the participants in the Gastarbeiter program, are likely to have what Anna Stilz (2013) has called 'located life plans' in the territory in which they reside. Such located life plans go beyond having a mere 'stake' in the politics of their place of temporary residence. It includes long-term and locally situated projects, relationships and commitments that are very fundamental to the structure of their lives. Denying them a right to political participation seems inconsistent with treating them as having equal moral status.

Even if many temporary migrants do not have a claim to rights to political participation in host countries based on their equal moral status, there still may be good reasons to enfranchise them. One reason is based on concern that temporary workers could become a kind of persistent minority, whose interests are continuously disregarded by other members of society, and whose basic rights are consequently poorly protected. While it is arguably true that the interests of each temporary worker will not be disregarded in the long-run because she will have left the state by then, it still may be

\footnotetext{
${ }^{24}$ For discussion of the all-affected principle, see Arrhenius 2005; Goodin 2007. For a defense of the all subjected principle see Abizadeh 2012). See also Lopez-Guerra 2005.
} 
that, as a group, temporary workers might be unlikely to have their interests taken seriously by voting members of society. This provides an instrumental reason to temporarily enfranchise temporary migrant workers. ${ }^{25}$ Of course, the root of this justification is that there are certain ways that temporary migrants must be treated, not that these workers have an intrinsic moral right to political participation due to the nature of their relationship to the state in which they reside. The idea is that, under current socio-political conditions, rights to political participation may prove necessary to, or highly conducive for, ensuring that they are treated fairly. This bears stressing. Previous experiences with temporary migration programs highlight the ways that political elites may be strongly disposed to see guest workers as nothing more than cheap labor and to lobby for legislation that allows them to be treated very badly. However, we take it that such rights should be part and parcel of the design of temporary migration programs, and not dependent on the political agency of the temporary workers themselves, who might be too busy working, or too focused on the political conditions of their country of origin, to mobilize in favour of their basic rights (see Ottonelli and Torresi 2010; 2014). Moreover, it is highly questionable whether granting such political rights to temporary migrant workers will have as much instrumental value as the argument supposes. In most cases, at least, temporary workers may be in a very small minority. And there may be other institutional measures that serve to protect their rights (Ottonelli and Torresi 2010; 2014).

There might be a second instrumental reason to enfranchise temporary workers that relates to the pedagogical effect of allowing them to experiment with a different political environment while residing abroad. We noted above that one of potential benefits of temporary migration are the positive effects these workers can have on the

\footnotetext{
25 This is stressed in Sager (2014, p. 3), who writes "political rights are a necessary means to effectively resist domination."
} 
economies of their countries of origin. Arguably, there is another important benefit associated with temporary migration: the capacity of temporary workers to imagine alternative political futures for their states of citizenship. Because motivation for active political engagement relies on the belief that an alternative social reality is possible, the opportunity to participate politically in the host country can be extremely valuable once these workers return home. ${ }^{26}$

Whether temporary migration engenders more active political agency in the country of origin is an empirical matter. If enfranchisement does indeed have this desirable effect, then affording rights to political participation may be a desirable feature of temporary migration programs for temporary workers and their states of origin. But this falls short of showing that temporary migration programs are permissible only if recipient states extend such rights to temporary workers. This is particularly relevant if it turns out that programs which extend such rights are undesirable to the electorate compared to programs that do not. If programs that do not extend such rights are more likely to be adopted and to enable the participation of a much larger number of migrant workers, they may be preferable, all things considered, to programs that do.

But how about other rights associated with citizenship, such as the right to stand for office and the right to permanent residency? Would we violate the equal moral status of these workers if we deny them the right to be elected for office and to stay permanently in their country of temporary residence if they so wish?

The right of adult members to stand for office is extremely important for the fairness of a democratic arrangement. Granting this right to temporary workers, however, would undermine the very rationale for temporary migration programs from the perspective of host states, namely that temporary workers help fill gaps in the labor

\footnotetext{
${ }^{26}$ Kapur and McHale (2005, pp. 174-175) offer some evidence in favour of the connection between residence abroad and political agency. They note that "exiles and diasporas have played an important part in the experiences of some of the renowned political figures of the last century who returned to transform their countries."
} 
market and that they contribute to the economy through the sale of their labor. Importantly, this might reduce considerably the benefits to prospective migrants and their states of origin. Indeed, it is not even clear that temporary workers should reside in the host country long enough to be able to appropriately contest an election and serve a full term in office. In any case, the same reasons for denying that temporary migrants have a claim based on recognition of equal moral status to vote apply here as well. Their connection to the political community is not such that they have a claim to full membership rights in that community, any more than other temporary visitors do.

The same is true of the right to settle permanently. It is extremely problematic to deny citizens the right to live permanently in their country of citizenship or to deny the occupancy rights of people who have lived in a territory for many years and have located life plans based there. But there is nothing problematic about making migration temporary, so long as it is truly temporary, and recognized to be so from the outset. The academic on a two-year fellowship, or the agricultural worker on a visa to work during a harvest, do not have their rights violated if they are not granted rights to remain after the expiration of their visas. So long as these workers are not refugees or stateless persons, encouraging their return does not treat them as having unequal moral status. Rather, they are treated as people with equal moral status who are not members of some political community, and thus lack some of the membership rights extended to members in full of that community.

\section{SOCIAL AND ECONOMIC RIGHTS}

One controversial aspect of many temporary migration programs (most notably the Braceros Program in the USA and the Gastarbeiter program in West Germany) was that 
temporary migrants accepted what was deemed to be unacceptably low pay or had various other socioeconomic rights left unprotected.

We need to distinguish different complaints that can be lodged against such programs. Let's first consider the idea of compensation. One possible complaint is that the temporary migrants accepted wages that were less than what domestic workers would have accepted. ${ }^{27} \mathrm{On}$ its face, this does not seem problematic. The fact that some will hold out for much higher wages than others is not typically a good reason to consider the compensation of those who take jobs to be too low. This seems to be a commonplace in the ordinary working of the labor market. Things seem a bit different if the wages that temporary workers accept could not permissibly be offered to those in the domestic market. In that case, we should at least need a rationale for this difference in treatment. If the reasons are that these wages are simply deemed too low, perhaps because they do not suffice for a living wage, or do not seem a fair return on the labor they use, these would also seem reasons why it should be unacceptable to offer them to temporary workers as well.

The issue is not that the wages are considered too low by members of the domestic workforce, but that they are in fact too low for the proper protection of anyone's basic interests. Indeed, the fact that the state coercively prevents members of the domestic workforce from taking such wages up clearly signals that they would make it hard for foreign workers to have their equal moral status recognized by members of the host society. Inequality in wages can only be justified if the state can provide a compelling reason why the reasons for prohibiting these contracts to native workers do not apply to temporary workers as well. One such reason could be based on the host state's taxation regime. If low wages for temporary workers are accompanied by generous tax breaks, such that temporary workers could still protect their basic rights

\footnotetext{
${ }^{27}$ For a detailed discussion, see Castles 2006. See also Ruhs 2010.
} 
even though native workers could not were they to receive the same wages, then this could be a legitimate reason for differential wages. In other words, the pay rate of temporary workers must be in line with the protection of basic rights. The mere fact that some workers are willing to receive a wage that does not allow them to protect their rights does not make it morally permissible for the state to make such offers. ${ }^{28}$

Another key threat to migrant workers is that employers may take unfair advantage of their vulnerability. They may misrepresent or make fraudulent claims regarding the nature of the work and the benefits the migrants will receive. The terms of the contract may not be adhered to by the employer since the workers may have limited ability to have their claims adjudicated. Further, businesses may not adhere to basic labor and health and safety standards that they are legally obligated to uphold. And host states may limit their movement (not least by confiscating their passports), or by withholding their wages. These practices are not consistent with treating temporary migrants as having equal moral status. ${ }^{29}$ Problems of this sort can and must be addressed through intelligent institutional design. For instance, Canada enforces work agreements in the native language of temporary workers, and expects the ministry of labor in the state of origin to brief workers on their rights prior to arrival in Canada (Abella 2006, p. 46). Mauritius has a Special Migrant Worker's Unit, which has both the mandate and resources to investigate abuse against temporary workers. This includes, among many things, making use of translators, frequent workplace inspections and a hotline to receive complaints (Ibid., p. 50).

Finally, some temporary migration programs have denied the right of migrant workers to change jobs. In principle, this need not be problematic—an employer sponsored system that protected workers from abuse and paid them a fair wage but

\footnotetext{
${ }^{28}$ The same distinction is relevant when it comes to other features of labor and safety conditions. ${ }^{29}$ See for example recent reports on the treatment of temporary workers in Singapore and the Gulf States. See Ruhs 2013 (and sources cited therein); Human Rights Watch 2016; Lori 2012; Longva 1999).
} 
restricted their right to change employers could be justified. In practice, however, such programs are certainly more likely to make workers vulnerable to abuse by their employers (Castles 2006, p. 2). Because in this case, visas are tied to on-going employment with a particular employer who initially sponsored them, guest workers are vulnerable to being placed in a position where they must choose between tolerating abuse at work and deportation. Indeed, in designing their temporary migration programs, states must not simply avoid restrictions on migrants that are ruled out by the requirement that they be treated as having equal moral status. They must also design institutions that reliably reduce the risks of abuse through non-compliance. If it is foreseeable that in poorly regulated industries, employers will take advantage of the vulnerability of guest workers, and that many workers will put up with all sorts of illegal abuse to remain in the host country, then a right to change employers on the part of workers becomes a moral requirement.

To be sure, in the case of previous guest worker programs it was often the case that workers consented to the employment conditions attached to their visa, and they were not deceived or coerced into doing so. But like with the question of pay, the fact of consent to domination on its own does not mean that workers were not wronged by the state that temporarily hosted them. ${ }^{30}$

It might be objected that the features of temporary programs that we deem problematic are what make them feasible. The idea here is that labor gaps exist if, and only if, the working conditions are very poor. The worry is that when states profess to be concerned with a labor gap in a certain industry, they are in fact seeking workers who are

\footnotetext{
${ }^{30} \mathrm{It}$ is also true that in previous guest worker arrangements, workers were not allowed to bring their spouses or children with them, even when residing in the host country for long periods (Castles 2006, p. 2). Temporary migration programs must be designed in ways that protect the basic right of workers to family life, but whether family members will have a right to join them will depend on the duration of these programs. If the program lasts for a few months only, it is not clear that a right to family life has been violated in cases where workers must enter the state on their own. In the case of programs that last much longer, host states must allow workers to bring family members with them.
} 
willing to accept to be paid less than what they need to protect their basic rights, as well as tolerate all forms of abuse on the part of their employers. This hidden agenda on the part of liberal states might partly work as a ploy to encourage domestic workers to reduce their demands.

This is a reasonable concern. And, as stressed above, the interests of workers in host countries must be taken adequately into account when assessing such programs. However, there are instances of temporary programs that do not seem problematic in these ways. Australia's temporary migration program, to take just one example, requires employers to pay the Australian market salary rate. ${ }^{31}$ This program has been used to attract workers to industries that are domestically unpopular, such as farming, construction, and mining. But the workers are not offered wages and working conditions that are forbidden to domestic workers.

Another worry is that enforcing the return of temporary workers can be more easily said than done, and that only authoritarian states can implement programs that genuinely count as temporary.

It is true that many foreign workers end up staying permanently in the recipient country. This may pose a problem for the feasibility of temporary migration programs. But it is important not to confuse an ideal with its perfect implementation, since the inability to enforce the return of all workers is not a decisive objection to temporary migration programs. The most effective and humane way of encouraging the return of foreign workers is to provide them with strong economic incentives to return. This could be done, for instance, by allowing workers to access part of their savings or tax refunds once they return home.

\footnotetext{
${ }^{31}$ From March 2018, this will be labeled Temporary Skill Shortage (TSS) visa. See Department of Immigration and Border Control 2017.
} 


\section{CONCLUSION}

In this essay, we've tried to show that the mere fact that some regimes do not extend political rights or guarantee a pathway to citizenship does not disqualify them morally, so long as they protect the basic rights of the migrants. We have argued that temporary workers of relatively short duration lack a moral claim to political participation, representation, and permanent residency. We have also claimed that the fact that such workers are willing to accept less pay than domestic workers for the same job does not disqualify them, so long as the domestic workers are not themselves forbidden to accept such conditions. We have also tried to spell out some of the features that such programs ought to have if they are to reliably treat temporary migrants as having equal moral status.

\section{References}

Abella, Manolo., 2006. Policies and best practices for management of temporary migration. Paper for the United Nations Secretariat. Available at http://www.un.org/esa/population/migration/turin/Symposium_Turin_files/P0 3_SYMP_Abella.pdf

Abizadeh, Arash. 2012. On the Demos and its Kin: Nationalism, Democracy, and the Boundary Problem. American Political Science Review 106:867-882.

Adams Jr., Richard H. and Page, John. 2005. Do International Migration and Remittances Reduce Poverty in Developing Countries. World Development 33:16451669.

Arneson, J. 1999. What, If Anything, Renders All Humans Morally Equal? Pp. 103-128 in Singer and His Critics, edited by Jamieson, D. Oxford: Blackwell.

Arrhenius, Gustav. 2005. The Boundary Problem in Democratic Theory. Pp. 14-29 in Democracy Unbound: Basic Explorations I, edited by Tersman, F. Stockholm: Filosofiskainstitutionen, StockholmsUniversitet.

Blake, Michael. 2013. Immigration, Jurisdiction, and Exclusion. Philosophy and Public Affairs 41:103-130. 
Brock, Gillian. and Blake, Michael. 2014. Debating brain drain: may governments restrict emigration?. Oxford: Oxford University Press.

Chami, Ralph, Fullenkamp, Connel and Jahjah, Sami. 2003. Are Immigrant Remittance Flows a Source of Capital for Development? IMF Working Paper (September 2003) 1-48. Available at SSRN: http://ssrn.com/abstract $=880292$.

Carens, Joseph H. 2010. Immigrants and the Right to Stay. Cambridge, MA: MIT Press. Carens, Joseph H. 2008. Live-in Domestics, Seasonal Workers, and Others Hard to Locate on the Map of Democracy. Journal of Political Philosophy 16:419-445.

Castles, Stephen. 2006. Back to the Future? Can Europe meet its Labour Needs though Temporary Migration? IMI Working Paper 1-40.

Chin, Rita. 2007. The Guest Worker Question in Postwar Germany. Cambridge: Cambridge University Press.

Clemens, Michael A. and McKenzie, David J. 2014. Why Don't Remittances Appear to Affect Growth?. World Bank Policy Research Working Paper No. 6856 (May 1, 2014). Available at SSRN: http://ssrn.com/abstract=2433809.

Collier, Paul and Hoeffler, Anke. 2002. Greed and Grievance in Civil War. World Bank Policy Research Working Paper No. 160.

Department of Immigration and Border Protection. 2017. Abolition and replacement of the 457 visa - Government reforms to employer sponsored skilled migration visas. Available at https://www.border.gov.au/Trav/Work/457-abolition-replacement Djajić, Slobodan. 2013. Some Essentials of a Workable Guest-Worker Program. International Economic Review 54:739-766.

Dustmann, Christian and Mestres, Josep. 2010. Remittances and Temporary Migration. Journal of Development Economics 92:62-70.

De Haas, Hein. 2005. International Migration, Remittances, and Development: Myths and Facts. Third World Quarterly 26:1269-1284.

Ferracioli, Luara. 2015. Immigration, self-determination, and the brain drain. Review of International Studies, 41: 99-115.

Goodin, Robert E. 2007. Enfranchising All Affected Interests, and Its Alternatives. Philosophy and Public Affairs 35:223-237.

Human Rights Watch. 2016. Singapore: Domestic Workers Face Grave Abuses. Available at https://www.hrw.org/world-report/2016/country-chapters/singapore\#f176e9.

IOM (International Organization for Migration). 2010. World Migration Report 2010 . Switzerland. 
Kapur, Devesh and McHale, John. 2012. The Economic Effects of Emmigration on Sending Countries. Pp. 131-152 in The Oxford Handbook of The Politics of International Migration, edited by Rosenblum, Marc R. and Tichenor, Daniel J. New York: Oxford University Press.

Kapur, Devesh and McHale, John. 2005. Give Us Your Best and Brightest: The Global Hunt for Talent and Its Impact on the Developing World. Washington, DC: Center for Global Development.

Kostakopoulou, Theodora. 2009. Citizenship Goes Public: The Institutional Design of Anational Citizenship. The Journal of Political Philosophy 17:275-306.

Lenard, Patti Tamara and Straehle, Christine. 2011. Temporary Labour Migration, Global Redistribution, and Democratic Justice. Politics, Philosophy \& Economics 11:211-218. Longva, Anh Nga. 1999. Keeping Migrant Workers in Check: The Kafala System in the Gulf. Middle East Report, No. 211, Trafficking and Transiting: New Perspectives on Labor Migration.

Lopez-Guerra, Claudio. 2005. Should Expatriates Vote? Journal of Political Philosophy 13: 216-234.

Lori, Noora. 2012. Temporary Workers or Permanent Migrants? The Kafala System and Contestations over Residency in the Arab Gulf States. Center for Migrations and Citizenship.

Miller, David. 2016. Strangers in Our Midst: The Political Philosophy of Immigration. Cambridge, MA: Harvard University Press.

Ottonelli, Valeria and Torresi, Tiziana. 2014. Temporary Migration Projects and Voting Rights. Critical Review of International Social and Political Philosophy 17:580-599.

Ottonelli, Valeria and Torresi, Tiziana. 2010. Inclusivist Egalitarian Liberalism and Temporary Migration: A Dilemma. Journal of Political Philosophy 20:202-224.

Pevnick, Ryan. 2011. Immigration and the Constraints of Justice. Cambridge: Cambridge University Press.

Pfutze, Tobias. 2009. Do Remittances Promote Democratization? How International Migration Helps to Overcome Political Clientilism. Unpublished Manuscript. Journal of Development Economics 2. Available at http://www.cgdev.org/doc/events/2.23.09/ Pfutze_Remittances_Democratization.pdf.

Rodrik, Dani. 2005. Feasible Globalizations. Pp. 196-213 in Globalization: What's New?, edited by Michael Weinstein. New York: Columbia University Press. 
Ruhs, Martin. 2013. The Price of Rights: Regulating International Labor Migration. Princeton: Princeton University Press.

Ruhs, Martin. 2010. Migrant Rights, Immigration Policy and Human Development. Journal of Human Development and Capabilities 11:259-279.

Ruhs, Martin. 2006. The Potential of Temporary Migration Programmes in Future International Migration Policy. International Labour Review 145:7-36.

Ruhs, Martin and Martin, Philip. 2008. Numbers vs Rights: Trade-Offs and Guest Worker Programs. International Migration Review 42:249-265.

Sager, Alex. 2014. Political rights, republican freedom, and temporary workers. Critical Review of International Social and Political Philosophy 17:189-211.

Stilz, Anna. 2013. Occupancy Rights and the Wrong of Removal. Philosophy and Public Affairs 41:324-356.

Waldron, Jeremy. 2002. God, Locke, and Equality. Cambridge: Cambridge University Press.

Walzer, Michael. 2008. Spheres of justice: A Defense of Pluralism and Equality. New York: Basic Books.

Wellman, Christopher H. 2008. Immigration and Freedom of Association. Ethics 119:109-141.

Williams, Bernard. 1962. The Idea of Equality. Pp. 110-131 in Philosophy, Politics and Society, series II, edited by Laslett, P. and Runciman, W. G. Oxford: Blackwell. World Bank. 2006. Global Economic Prospects 2006: Economic Implications of Remittances and Migration. Washington, DC: The World Bank.

Ypi, Lea. 2016. Taking Workers as a Class: The Moral Dilemmas of Guestworker Programmes. in Migration in Political Theory: The Ethics of Movement and Membership, edited by Fine, S. and Ypi. L. Oxford: Oxford University Press 